\title{
An early record of ball lightning: Oliva (Spain), 1619
}

\section{Fernando Domínguez-Castro}

Instituto Pirenaico de Ecología, Consejo Superior de Investigaciones Científicas, Zaragoza, 50059, Spain

Correspondence: Fernando Domínguez-Castro (f.dominguez.castro@gmail.com)

Received: 23 February 2018 - Accepted: 5 May 2018 - Published: 24 May 2018

\begin{abstract}
In a primary documentary source we found an early record of ball lightning (BL), which was observed in the monastery of Pi (Oliva, southeastern Spain) on 18 October 1619. The ball lightning was observed by at least three people and was described as a "rolling burning vessel" and a "ball of fire". The ball lightning appeared following a lightning flash, showed a mainly horizontal motion, crossed a wall, smudged an image of the Lady of Rebollet (then known as Lady of Pi) and burnt her ruff, and overturned a cross.
\end{abstract}

\section{Introduction}

There is no generally accepted description of ball lightning (BL). The most commonly used descriptions are based on statistical analyses of reports of BL (thousands in the last three centuries), and these highlight the most common features. One of these descriptions, provided by Stenhoff (1999), is that "it is associated with thunderstorms. It is luminous and roughly spherical, with a modal diameter of $20-50 \mathrm{~cm}$ and a lifetime of several seconds. It moves independently through the air, often in a horizontal direction". BL has aroused the curiosity of scientists since 1854, when Arago made the first attempt to compile evidence of the phenomenon (Arago, 1854). He concluded that BL represents "one of the most inexplicable problems of physics today". Since that time BL has attracted the attention of scientists, but full understanding of the phenomenon remains a challenge. Some scientists expressed doubts about the existence of BL (cf. Campbell, 1992) and speculated that most of the reports of its occurrence could be explained by other well-known phenomena, including cloud-to-ground lightning, cloud-tocloud lightning, St. Elmo's fire, will-o'-the-wisp, or mistaken perception of eyewitness (Cooray and Cooray, 2008; Peer and Kendl, 2010). The skepticism ended gradually, and in particular in the summer of 2012, when Cen et al. (2014) unintentionally (they were studying cloud-to-ground lighting) filmed a possible occurrence of ball lightning on the Tibetan Plateau (China), using two slitless spectrographs. However, the physics underpinning BL is unclear. Any model of BL (electrostatic, electrochemical, charged aerosols and fractals, nuclear, plasma, etc.; for reviews see Donoso et al., 2006; Oreshko, 2015) must predict all the reported characteristics of BL. Moreover, any experiment to generate BL must fully replicate its properties (for reviews see Bychkova et al., 2016; Stephan et al., 2016; Wu, 2016).

BL is difficult to study because the events are short lived and unpredictable. For these reasons reports of BL observations are the most important sources of information about the nature of the phenomenon. Thousands of reports were compiled during the 20th century and more recently (Brand, 1923; Humphreys, 1936; McNally, 1961; Barry, 1967; Keul, 1981; Ohtsuki and Ofuruton, 1987; Egely, 1989; Meaden, 1990; Bychkov et al., 1993; Hubert, 1996; Keul and Stummer, 2002; Keul et al., 2006), and the importance of historical records in understanding the phenomenon is well-recognized (Coleman, 2006; Durand and Wilson, 2006; Farrona and Vaquero, 2012; Vaquero, 2017). However, there are few accurately dated records providing precise and realistic descriptions prior to 1650 . In this short note we present a welldocumented report of an observation of BL made on 18 October 1619 at Oliva, in southeast Spain.

\section{The ball lightning report}

The BL report was found in a manuscript entitled "Coses evengudes en la ciutat y regne de Valencia" (Things that happened in the city and kingdom of Valencia), authored by Pere Joan Porcar (Porcar, 1628). The manuscript (Porcar 1589-1628) is held in the archive of the Real Academia de la Historia (Royal Academy of History) in Madrid, Spain. 


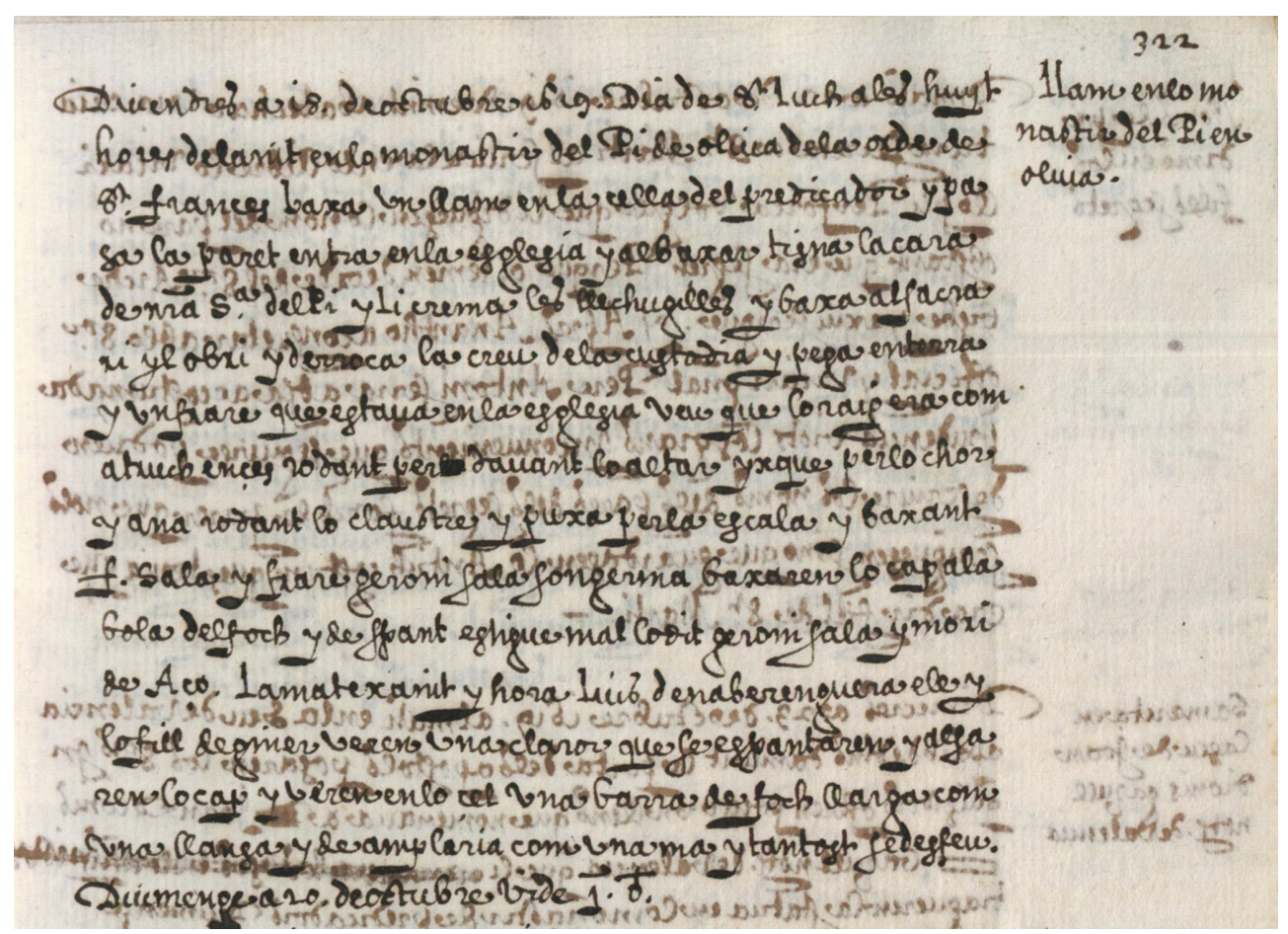

Figure 1. Detail of the manuscript Coses evengudes en la ciutat y regne de Valencia (courtesy of the Real Academia de la Historia).
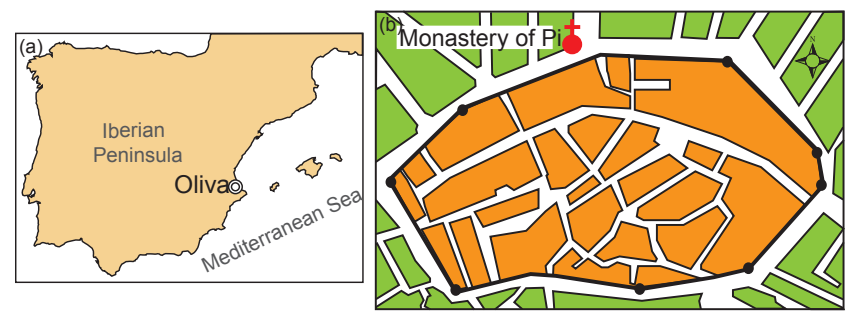

Figure 2. (a) Location of Oliva (b) map of Oliva from the early 17th century (modified from Brines et al., 1988).

It is a diary that covers the period from 1 January 1589 to 30 December 1628 and includes 3392 records covering a wide range of social, political, environmental, and astronomical topics. The diaries are primary documentary sources that emerged in Iberia during the late 14th century as an evolution of the chronicles. The diarists reported events they saw or were informed of (for details of diaries from the Valencia region during the 17th century, see Escartí, 1988, 1990, 2010). Many of the earliest records of BL have been retrieved from secondary sources (i.e., not contemporaneous with the described events). These sources commonly involve uncertainty in dates (Vaquero et al., 2017) or in the descriptions of the event. For example, Atkyns (1712) described a BL that occurred at 1556 as a "fiery sulphureous globe rolling in at the parlour door". This reference to a globe is not in the description of Rudder (1779), which records that "light- ning entered at the parlour door, and forced its way out at the window at the opposite side of the room". The author of the manuscript (Pere Joan Porcar) was born in 1560 at Valencia. He belonged to the low Valencian secular clergy, gave sacraments, and helped in the tasks derived from the liturgy. The date of his death is not certain, but was probably 1629 (García García, 1983). In most of the diary entries Pere Joan Porcar is represented as an external observer recording facts; only in few records concerning politics is there evidence of inclusion of some personal opinion.

The report of BL from the original manuscript in Catalan is shown in Fig. 1. Here we provide a transcript and an English version of the text:

\section{Llamp en lo monastir del Pi en Oliva}

Divendres a 18 Octubre 1619 dia de Sant Luch a les huyt hores de la nit en lo monastir del Pi de oliva de la orde de Sant frances, baxa vn llam en la cella del predicador y pasa la paret entra en la esglesia y al baxar tisna la cara de nostra señora del Pi y li crema les lechugilles y baxa al sacrari yl obrí y derroca la creu de la custodia y pega en terra y vn frare que estaua en la esglesia veu que lo raig era com atruch encés rodant per dauant lo altar ixque per lo chor y ana rodant lo claustre $y$ puxa per la escalera y baxant $f$. sala y frare geroni Sala son germa baxaren lo cap a la bola de foch y de spant estingue mal lo dit geroni sala i mori de açò. La matexa nit y hora luís de na berebguera, ell 

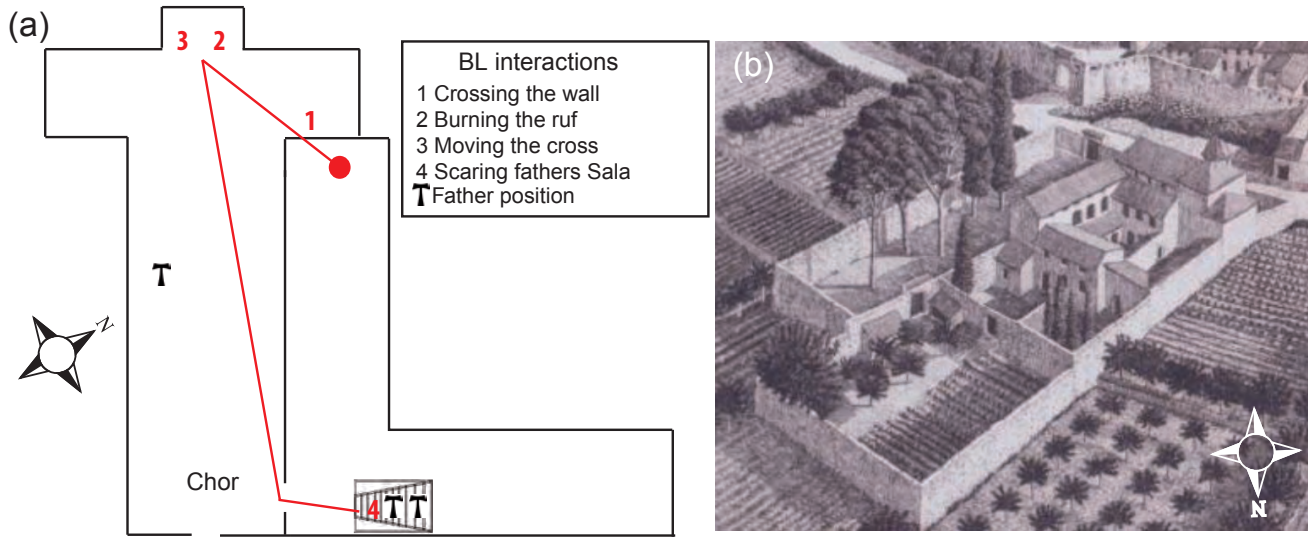

Figure 3. (a) Schematic map of monastery of Pi with the motion of the ball lightning. (b) Detail of the Approximate view of Oliva around 1850 by Enrique Bofí Planes (courtesy of the Museo Nacional de Cerámica y Artes Suntuarias González Martí).

y lo fill de giner veren vna claror que se espantaren y alsaren lo cap $i$ veren en lo çel vna barra de foch llarga com vna llansa y de amplaria com una ma y tantost se desfeu.

Lightning in the monastery of Pi at Oliva

Friday 18th October 1619, Saint Luke day, at 20:00, at the Monastery of Pi of Oliva, Franciscan order, a lightning strikes at the preacher's cell, crosses the wall and comes into the church, and falling to the tabernacle smudges the face of Our Lady of $\mathrm{Pi}$ and burns her ruff, goes down to the tabernacle and opens it, and overturns the Jerusalem Cross and hits the ground. A father that was in the church saw that the lightning was like a burning rolling vessel above the altar; it exited by the choir and rolled by the cloisters and climbed up the stairs. Descending the stairs were father Sala and father Geroni Sala, brothers; they lowered their heads to the ball of fire and, sick with fear, the aforementioned Geroni Sala died from that. The same night and time, Luis de Berbguera and the son of Giner see a scary glow. They look up and see in the sky a bar of fire as long as a spear and as wide as a hand that immediately vanished.

\section{Analysis of the BL report}

The BL was observed in Oliva in the monastery of $\mathrm{Pi}$, located at $38^{\circ} 55^{\prime} 17^{\prime \prime} \mathrm{N}, 0^{\circ} 07^{\prime} 11^{\prime \prime} \mathrm{W}$ (Fig. 2a). The monastery is now the "El Rebollet" school, and, although the church remains, the buildings have been substantially modified since the 17th century. During the 17th century the monastery was outside the city wall and surrounded by agricultural fields (Fig. 2b).

Figure 3 shows a schematic map of the monastery, provided to clarify the path of the BL. The BL appeared in the "preached cell"; the precise location of the cell is unclear, but

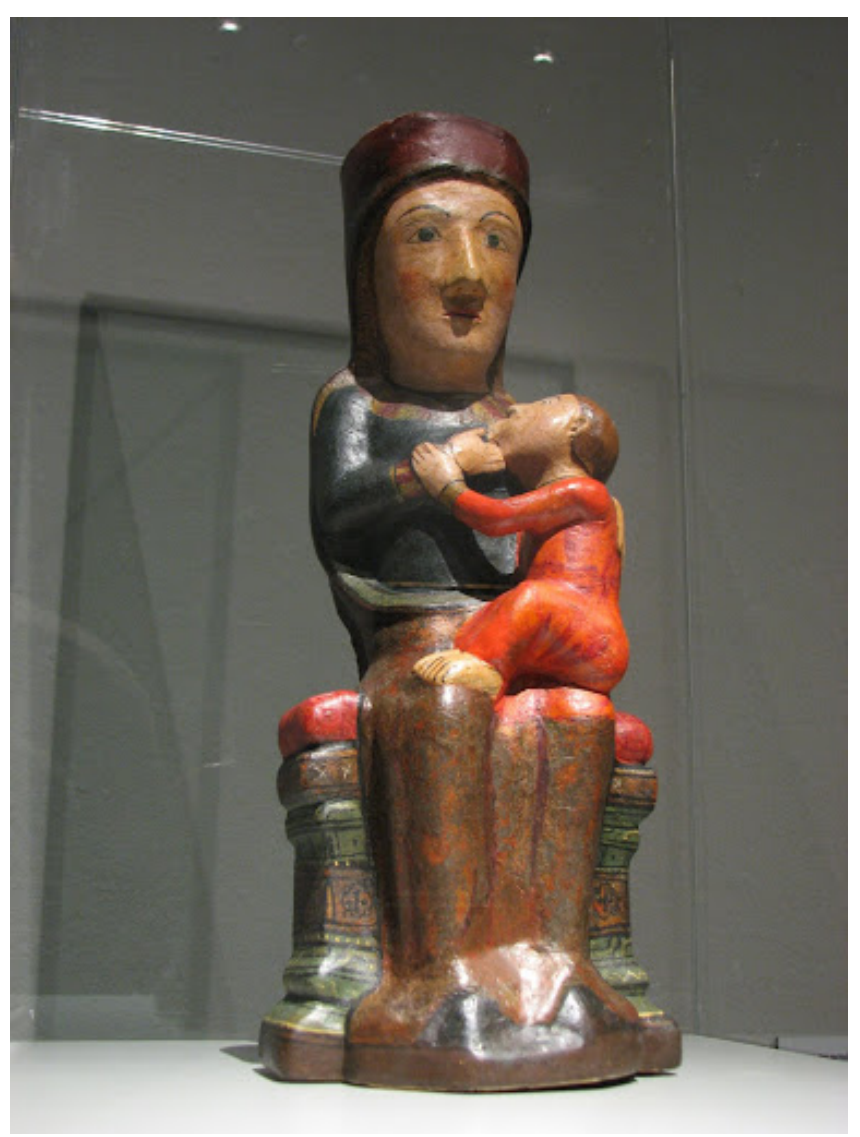

Figure 4. Sculpture of Our Lady of Rebollet (Pastoral, 2018).

it did share a wall with the church and was probably on the second floor. The BL crossed that wall and appeared in the church. The crossing of walls, windows, and aircraft fuselages is a very commonly reported feature of BL (Grigorev, 1992). Bychkova et al. (2016) studied the passage of a BL through a window, and Torchigin and Torchigin (2016), con- 
sidering BL a self-confined light, explained its ability to cross walls.

The BL entered the church and "falling to the tabernacle smudged the face of Our Lady of Pi and burns her ruff'. Our Lady of Pi (now known as the Lady of Rebollet) is a sculpture $38 \mathrm{~cm}$ high and $15 \mathrm{~cm}$ wide made of birch wood (Fig. 4). Because of the possible electrical properties of BL it is important to note that at the time the image was backed by an iron plate having a ring fixed to the image by four nails. The BL burnt the wood and the ruff (a collar of lace, commonly used during the 16th and 17th centuries). Thermal effects of BL have been frequently reported (e.g., Stenhoff, 1976; Corliss, 1982). Holes burnt in a dress by BL (described by Stenhoff, 1988) were studied by Wooding (1976) to estimate the thermal properties of the $\mathrm{BL}$.

The report goes on to describe that the BL "open the tabernacle and overturn the Jerusalem Cross". Opening of locked doors is not a previously described feature of BL, although it has been widely reported that BL can move and break objects (e.g., Tomlinson, 1848; Flammarion, 1905; Cade and Davis, 1969; Singer, 1971). It seems possible that the tabernacle was unlocked and was opened when the cross was affected by the BL and fell.

A father in the church described the BL as a "burning rolling vessel", and later in the report it is described as a "ball of fire". Statistical analyses of BL reports indicate that the most common shape of BL is spherical, with a diameter of approximately $25 \mathrm{~cm}$ (Stenhoff, 1999), which is consistent with the possible dimension of a 17th century vessel. Fire colors and spinning or rotating motion are commonly reported characteristics of BL (Rayle, 1966).

The last to see the BL were the Sala brothers. They had no contact with the BL, but Geroni Sala died at the sight of the $\mathrm{BL}$. The most plausible cause of his death is myocardial infarction triggered by the "extreme" experience of seeing the BL. Other extreme experiences have been reported to trigger myocardial infarctions, including earthquakes (Suzuki et al., 1995) and missile strikes (Meisel et al., 1991). Unfortunately, the decay of the BL was not reported.

At the end of the record, Pere Joan Porcar reported that two observers "at same night and time" saw a lightning flash described as "a bar of fire long as a spear and wide as a hand, and immediately vanished". Approximately $80 \%$ of reports of BL indicate that this phenomenon is observed following a lightning flash (McNally, 1966; Rayle, 1966).

\section{Conclusions}

We have reported a primary documentary source detailing the occurrence of BL on 18 October 1613. The report objectively describes BL that appeared following a lightning flash. The BL had a mainly horizontal motion, crossed a wall, smudged an image of the Lady of Rebollet and burnt her ruff, and over- turned a cross. At least three people observed the BL and described it as a "rolling burning vessel" and a "ball of fire".

Data availability. No data sets were used in this article.

Competing interests. The author declares that he has no conflict of interest.

Acknowledgements. The author is grateful to Natxo Sorolla, Natalia Martín, and Miquel Tomás Burguera for their help in the translation of the original text. He wants to thank the EU and Spanish Ministry of Economy and Competitiveness for funding within the framework of the collaborative international consortium IMDROFLOOD financed under the ERA-NET Cofund WaterWorks 2014 Call, an integral part of the 2015 Joint Activities conducted by the Water Challenges for a Changing World Joint Programme.

Edited by: Kristian Schlegel

Reviewed by: Axel Wittmann and one anonymous referee

\section{References}

Arago, F.: Oeuvres completes, Barral M. J. A., Paris, 1854.

Atkyns, T.: The Ancient and Present State of Gloucestershire, W. Bowyer, London, 1712.

Barry, J. D.: Ball lighting, J. Atmos. Terr. Phys., 29, 1095-1101, 1967.

Brand, W.: Der Kugelblitz: Probleme der Kosmischen Physik, H. Grand, Hamburg, Reprinted by Verlag Kessel, Remagen, Germany, 2010, 1923.

Brines, F., Camarena, J., Cardona, S., Climet, J., Frasés, M., García, M., Mestre, A., Pla, E., Pons Fuster, F., Pons Moncho, F., Soler, C., and Vicéns, M.: Iniciación a la historia de Oliva, Publicaciones del Ayuntamiento de Oliva, Valencia, 1988.

Bychkov, V. L., Smirnov, B. M., and Stridjev, A. J.: Analysis of the Russian-Austrian ball lightning data banks, J. Meteorol., 18, 113-120, 1993.

Bychkova, V. L., Nikitinb, A. I., Ivanenkoa, I. P., Nikitinab, T. F., Velichkob, A. M., and Nosikovc, I. A.: Ball lightning passage through a glass without breaking it, J. Atmos. Sol.-Terr. Phy., 150-151, 69-76, 2016.

Cade, C. M. and Davis, D.: Taming of the Thunderbolts, AbelardSchuman, New York, 1969.

Campbell, S.: Great balls of fire, The Skeptic, 6, 12-21, 1992.

Cen, J., Yuan, P., and Xue, S.: Observation of the optical and spectral characteristics of ball lightning, Phys. Rev. Lett., 112, 035001, https://doi.org/10.1103/PhysRevLett.112.035001, 2014.

Coleman, P. F.: Ball lightning fireballs seen in the 1783 Laki vog, Weather, 61, 293-294, 2006.

Cooray, G. and Cooray, V.: Could some ball lightning observations be optical hallucinations caused by epileptic seizures?, Open Atmos. Sci. J., 2, 101-105, 2008. 
Corliss, W. R.: Lightning, auroras, nocturnal lights, and related luminous phenomena, in: A Catalog of Geophysical Anomalies, Sourcebook Project, Glenarm, Maryland, 1982.

Donoso, J. M., Trueba, J. L., and Rañada, A. F.: The riddle of ball lightning: a review, Sci. World J., 6, 254-278, 2006.

Durand, M. and Wilson, J. G.: Ball lightning and fireballs during volcanic air pollution, Weather, 61, 40-43, 2006

Egely, G.: Hungarian ball lightning observations in 1987, in: Science of Ball Lightning (Fireball), World Scientific, Singapore, 1989.

Escartí, V. J.: Literatura memorialística valenciana del segle XV al XVIII, Tres i Quatre, València, 1988.

Escartí, V. J.: Unes consideracions sobre la dietarística valenciana del segle XVII, Revista Internacional de Filologia, 9, 119-127, 1990.

Escartí, V. J.: Notícia sobre la literatura memorialística al País Valenciá, del segle XIV al XIX, Manuscrits, 28, 181-205, 2010.

Farrona, A. M. M. and Vaquero, J. M.: An early scientific report of ball lightning from Brazil, Weather, 67, 96-97, 2012.

Flammarion, C.: Thunder and Lightning, Chatto and Windus, London, 1905.

García García, F.: Dietari, 1589-1628 (antología), Diputación Provincial de Valencia, Valencia, 1983.

Grigorev, A. I., Grigoreva, I. D., and Shiraeva, S. O.: Ball lightning penetration into closed rooms: 43 eyewitness accounts, J. Scientific Exploration, 6, 261-279, 1992.

Hubert, P.: Nouvelle enquête sur la foudre en boule analyse et discussion des résultats, report $\mathrm{PH} / \mathrm{SC} / 96001$, Commisariat a l'Energie Atomique, Service d'Electronique Physique, Centre d'Etudes Nucleaires de Saclay, France, 1996.

Humphreys, W. J.: Ball lightning, P. Am. Philos. Soc., 76, 613-626, 1936.

Keul, A. G.: Ball Lightning reports, Naturwissenschaften, 68, 134136, 1981.

Keul, A. G. and Stummer, O.: Comparative analysis of 405 Central European ball lightning cases, J. Meteorol., 27, 385-393, 2002.

Keul, A. G., Hentschel, K. H., and Stummer, O.: German ball lightning data bank results, in: Proceedings of the Ninth International Symposium on Ball Lightning, ISBL-06, 16-19 August 2006, Eindhoven, 96-105, 2006.

McNally, J. R.: Ball lightning: a survey, B. Am. Phys. Soc., 6, 202, 1961.

McNally, J. R.: Preliminary Report on Ball Lightning, Report No. ORNL-3938, Oak Ridge National Laboratory, Tennessee, 1966.

Meaden, G. T.: Ball lightning studies, J. Meteorol., 15, 114-196, 1990.
Meisel, S. R., Kutz, I., Dayan, K. I., Pauzner, H., Chetboun, I., Arbel, Y., and David, D.: Effect of Iraqi missile war on incidence of acute myocardial infarction and sudden death in Israeli civilians, Lancet, 338, 660-661, 1991.

Ohtsuki, Y. H. and Ofuruton, H.: Nature of ball lightning in Japan, Il Nuovo Cimento, 10, 577-580, 1987.

Oreshko, A. G.: An investigation of the generation and properties of laboratory-produced ball lightning, J. Plasma Phys., 81, 1-18, https://doi.org/10.1017/S0022377815000197, 2015.

Pastoral: available at: http://www.preguntasantoral.es/tag/ virgen-del-rebollet/, last access: 11 February 2018.

Peer, J. and Kendl, A.: Transcranial stimulability of phosphenes by long lightning electromagnetic pulses, Phys. Lett. A, 374, 2932 2935, 2010.

Porcar P. J.: Coses evengudes en la ciutat y regne de Valencia, Collection Salazar y Castro, volume G70, signature M-RAH, 9/517, 1628.

Rayle, W. D.: Ball lightning characteristics, NASA Tech. Note, NASA-TN-D-3188, National Aeronautics and Space Administration, Washington, DC, 1966.

Rudder, S.: The New History of Gloucestershire, Cirencester, England, 1779.

Singer, S.: The Nature of Ball Lightning, Plenum Press, New York, 1971.

Stenhoff, M.: Ball lightning, Nature, 260, 596-597, 1976.

Stenhoff, M.: A survey of ball lightning, J. Met., 13, 197, 1988.

Stenhoff, M.: Ball Lightning: An Unsolved Problem in Atmospheric Physics, Kluwer Stott Academic Publisher, New York, 1999.

Stephan, K. D., Krajcik, R., and Martin, R. J.: Fluorescence caused by ionizing radiation from ball lightning: Observation and quantitative analysis, J. Atmos. Sol.-Terr. Phy., 148, 32-38, 2016.

Suzuki, S., Sakamoto, S., Miki, T., and Matsuo, T.: Hanshin-Awaji earthquake and acute myocardial infarction, Lancet, 345, 981, https://doi.org/10.1016/S0140-6736(95)90727-0, 1995.

Tomlinson, C.: The thunder-storm: or, an account of the nature, properties, dangers, and uses of lightning, in various parts of the world, Society for Promoting Christian Knowledge, London, 1848.

Torchigin, V. P., and Torchigin, A. V.: How Ball Lightning penetrates in room through small holes and splits, Optik, 127, 61556161, 2016.

Vaquero, J. M.: Ball lightning: a Renaissance account from Zafra (Spain), Hist. Geo Space. Sci., 8, 53-56, https://doi.org/10.5194/hgss-8-53-2017, 2017.

Wooding, E. R.: Ball lightning in Smethwick, Nature 262, 379-380, 1976.

Wu, H. C.: Relativistic-microwave theory of ball lightning, Sci. Rep., 6, 1-9, https://doi.org/10.1038/srep28263, 2016. 